\title{
A First Record of Phlebotominae from Argentinean Patagonia (Diptera: Psychodidae: Phlebotominae)
}

\author{
Javier Muzón, Gustavo R Spinelli, O scar D Salomón*/+ , Gustavo C Rossi**
}

\author{
Departamento Científico de Entomología, Museo de La Plata, s/no., La Plata, Argentina *Centro Nacional de Diagnóstico e \\ Investigación en Endemo-Epidemias, Av. Paseo Colón 568, 1063 Buenos Aires, Argentina **Centro de Estudios Parasitológicos \\ y de Vectores, La Plata, Argentina
}

A species of the Lutzomyia oswaldoi group is recorded from the Valcheta stream basin, Somuncura plateau, Patagonia. It represents the World southermost record of a species of Phlebotominae, apparently supporting the hypothesis about the relictual character of several components of the Somuncura plateau biota, particularly for those species belonging to the Paranaense lineages.

Key words: Lutzomyia - Patagonia - Argentina

The subfamily Phlebotominae is represented in the Neotropics by the genera Lutzomyia França, 1924, Brumptomyia França \& Parrot, 1921, and Warileya Hertig, 1948.

The genus Lutzomyia is presently known by aproximately 400 species, among them the only proven vectors of leishmaniasis in the New World (Young \& Duncan 1994). From this large number, 17 inhabit Argentina (Spinelli et al. 1999), the majority of them restricted north to $29^{\circ} \mathrm{S}$, coincidentely with the southern border of leishmaniasis transmission (Salomón et al. 2001, 2002). However, L. cortelezii (Brèthes, 1923) is known to occur also around $35^{\circ} \mathrm{S}$, from 1920's captures at La Plata, Argentina (its type-locality) and Montevideo, Uruguay. Despite many efforts, up to now it has not been found again at this latitude.

During the development of a research project on the biodiversity of the aquatic entomofauna in Patagonia, headed by two of the authors (JM amd GRS), a male of Lutzomyia sp. was collected from a Malaise trap (Young \& Duncan 1994) operated between November 30 and December 2, 1999, near a spring of the Valcheta stream basin, Estancia “El Rincón” (4059’24.1”S -6640’35.7” W; 620 $\mathrm{m}$ altitude), in the Somuncura plateau. This was the unique Phlebotominae finding in this area, although spring/summer collections with the same methodology were made in

Field work was supported by the Agencia Nacional de Promoción Científica y Tecnológica-FONCyT grant PICT 01-02327, and CONICET grant PIP 0788.

${ }^{+}$Corresponding author. Fax: 54-11-43312536. E-mail: daniel@hotmail.com

OD Salomón and GR Spinelli are members of "Carrera del Investigador Científico", CONICET

Received 22 October 2001

Accepted 17 April 2002
1988, 1994, 1995, 1996, and 1998. The Lutzomyia sp. was found in a trap that had been used periodically for five years, always in Patagonia. Thus, a contamination due to a previous use of the Malaise trap was discarded.

The specimen was slide mounted in Canada balsam (Young \& Duncan 1994), and deposited in the collection of the Museo de La Plata, Argentina. It is in good shape (except for the legs, which are lost) and probably belongs to a new species of the oswaldoi group (Theodor, 1965), resembling L. quechua (Martins, Llanos \& Silva, 1975). L. quinquefer (Dyar, 1929) is the only species of this group recorded from Argentina north to $28^{\circ} \mathrm{S}$, while L. quechua is known to occur only in Peru.

This communication reports the southermost record of a Phlebotominae in the World, being the previous records Australophlebotomus brevifilis (Tonnoir, 1935) and A. brevifiloides Fairchild, 1952 from mainland Victoria, Australia (Lewis \& Dyce 1982). On the other hand, the northern limit of the distribution area of Phlebotominae is represented by L. vexator (Coquillett, 1907) from Perth, Ontario, Canada (Downes 1972) up to $44^{\circ} \mathrm{N}$. It will be very interesting to compare the adaptation strategies of both species to extreme contrasted seasonality and its probable diapause mechanisms.

The presence in the patagonian Somuncura plateau of a taxon which typically inhabits tropical and subtropical environments is also interesting from a biogeographical viewpoint. The streams in the area are mainly fed by springs (some with thermal traits), and among them, the Valcheta basin is distinctive by its length and permanence (Canevari et al. 1999). The northern slope of the Somuncura plateau is considered as an ecotone between the Monte and Patagonic domains (León et al. 1998) and, its entomofauna is characterized by a conjunction of Neotropical, Andean, and Subantarctic lineages (Muzón 1997, Spinelli \& Muzón 2000). The presence of Lutzomyia could contribute to the hypothesis about the relictual character of several components of the Somuncura plateau biota, particularly for those species belonging to Paranaense lineages (Ringuelet 1961, Menni \& Gómez 
1995). Thus, sand fly focussed trapping in the area is ongoing in order to describe the new species, and to support the mentioned hypothesis.

\section{REFERENCES}

Canevari P, Blanco DE, Bucher EH, Castro G, Davidson I 1999. Los Humedales de la Argentina: Clasificación, Situación Actual, Conservación y Legislación, 2nd. ed., Wetlands International Publ 46, Buenos Aires, 208 pp.

Downes JA 1972. Canadian records of Phlebotomus vexator, Trichomyia nuda, and Maruina lanceolata (Diptera: Psychodidae). Can Entomol 104: 1135-1136.

León RJC, Bran D, Collantes M, Paruelo JM, Soriano A 1998. Grandes unidades de vegetación de la Patagonia extra andina. Ecología Austral 8: 125-144.

Lewis DJ, Dyce AL 1982. The subgenus Australophlebotomus Theodor of Phlebotomus Rondani and Bert (Diptera: Psychodidae). J Aust Entomol Soc 21: 37-54.

Menni RC, Gómez SE 1995. On the habitat and isolation of Gymnocharacinus bergi (Osteichthyes: Characidae). Environ Biol Fish 42: 15-23.

Muzón J 1997. Odonata (Insecta) from Patagonia: species rich- ness and distributional patterns. Biogeographica 73: 123133.

Ringuelet RA 1961. Rasgos fundamentales de la zoogeografía de la Argentina. Physis 22: 151-170.

Salomón OD, Rossi GC, Spinelli GR 2002. Ecological aspects of Phebotomine (Diptera, Psychodidae) in an endemic area of tegumentary leishmaniasis in the Northeastern Argentina, 1993-1998. Mem Inst Oswaldo Cruz 97: 163-168.

Salomón OD, Sosa Estani S, Rossi GC, Spinelli GR 2001. Presencia de Lutzomyia longipalpis y situación de la leishmaniosis visceral en Argentina. Medicina (Buenos Aires) 61: 174-178.

Spinelli GR, Muzón J 2000. A viewpoint on Patagonian biogeography from the Ceratopogonidae case (Insecta: Diptera). Biogeographica 76: 125-132.

Spinelli GR, Rossi GC, Rodríguez EA 1999. Further notes on Phlebotominae from Argentina (Diptera: Psychodidae). Rev Soc Entomol Argent 58: 197-200.

Young DG, Duncan MA 1994. Guide to the identification and geographic distribution of Lutzomyia sand flies in Mexico, the West Indies, Central and South America (Diptera: Psychodidae). Mem Amer Entomol Inst 54: 1-881. 